Article

\title{
Toward the Dissemination of Sustainability Issues through Social Media in the Higher Education Sector: Evidence from an Italian Case
}

\author{
Elena Gori ${ }^{1, * \mathbb{C}}$, Alberto Romolini ${ }^{2}$, Silvia Fissi ${ }^{1}{ }^{1}$ and Marco Contri ${ }^{3}$ \\ 1 Department of Business and Economics, University of Florence, Via delle Pandette 9, 50127 Florence, Italy; \\ silvia.fissi@unifi.it \\ 2 Faculty of Economics, International Telematic University Uninettuno, Corso Vittorio Emanuele II 39, \\ 00186 Rome, Italy; a.romolini@uninettunouniversity.net \\ 3 Department of Economics and Management, University of Pisa, Via Cosimo Ridolfi 10, 56124 Pisa, Italy; \\ marco.contri@phd.unipi.it \\ * Correspondence: elena.gori@unifi.it
}

Received: 27 April 2020; Accepted: 5 June 2020; Published: 7 June 2020

\begin{abstract}
Nowadays, universities play a pivotal role in building a more sustainable society, promoting sustainable development by reducing the negative impacts of their activities. Accordingly, universities have been incorporating sustainability into the different dimension of their activities (i.e., campus operations, research, teaching, and community engagement). Against this backdrop, the active involvement of stakeholders is a critical element, and, in this regard, social media platforms are particularly well-suited tools thanks to their inherent dialogic features. While there are several studies on the implementation of sustainability within university activities, only a few previous researches explore whether and how such institutions use social media platforms (SM) to disclose their green initiatives and engage users. Based on this, our paper aims to fill the literature gap by exploring the case of the University of Florence. To achieve this aim, we performed a content analysis of the posts published by the university on Facebook. In contrast with prior studies which found scarce use of SM to share green activities in the higher education sector, our findings reveal that the University of Florence has been using SM to disclose their sustainability initiatives. Moreover, our results suggest that most posts are related to the community engagement dimension, while previous research pointed out prevalent attention to the environmental aspect. Finally, this research reveals a low interaction level between the university and its followers, which greatly hampers the dialogic potential of social platforms themselves.
\end{abstract}

Keywords: sustainability; social media; dialogic communication; higher education sector

\section{Introduction}

In recent years, governments, public companies and private firms have paid increasing attention to sustainability issues, incorporating them into their strategies [1]. In this regard, Cooper and Gorman [2] highlighted that universities can actively contribute to global sustainable development by developing knowledge through research and offering students high-quality training paths.

Over time, therefore, universities have become increasingly interested in the topic of sustainability and tried to integrate sustainability into the different dimensions which characterize their activity [3] including campus operations, teaching, research, and community engagement $[4,5]$. However, higher education institutions follow different paths to achieve this goal [6,7]. In the 1980s only a few universities considered it relevant for their activities, even if they found some difficulties [8]; today an increasing 
number of higher education institutions around the world have integrated sustainability into their own planning, marketing, and communication challenges [9,10].

More recently, there has also been an increasing trend in using social media within universities' activities [11,12]. According to Kaplan and Haenlein [13], social media are applications, based on digital technologies and developed in the context of Web 2.0, which allow users to create and share contents. Agostino and Arnaboldi [14] (p. 1292) also highlighted that social media "is a broad concept that [...] includes [s] a whole variety of different networking sites, such as Facebook, micro-blogging services like Twitter, blogs, photo sharing and video sharing websites like YouTube or Flickr." Some studies have also shown that, except for rare cases of excellence, organizations often use social media in a traditional way (i.e., asymmetrical and top-down) $[15,16]$, without actually activating an effective two-way communication with stakeholders [17].

The first aim that universities initially followed was to develop dialogue through social media [18], especially with students and potential freshmen [19], in order to support the recruitment initiative [20]. However, in recent years, communication through social platforms has extended to all other (and numerous) university stakeholders, making it a topic more and more relevant, including for the issue of sustainability.

The literature shows several contributions focusing on sustainability or on the use of social media in universities. However, so far there has been a lack of research that investigates these two aspects simultaneously. In other words, to the best of our knowledge, only a few studies have been conducted on the use of social media for the communication of sustainability matters in universities, and on the type of communication that these institutions establish with their stakeholders [21].

Based on this, this study aims to analyze the level of interaction between universities and social media users about the sustainability issue.

The paper proceeds as follows. The Section 2 summarizes a literature review by describing the current state of knowledge about the issue, the Section 3 illustrates the research method, and the Section 4 outlines the results. Finally, some concluding remarks are offered, explaining the limits and highlighting future research developments.

\section{Literature Review}

As recently confirmed by the UN Agenda 2030 and the UNESCO (United Nations Educational, Scientific, and Cultural Organization) initiative Education for Sustainable Development, universities play a pivotal role in building a more sustainable society [22] and in achieving the UN's Sustainable Development Goals [23].

Many of today's universities appear to be "small cities" in size and population and thus have a significant impact on the economy, society, and the environment [8]. Moreover, they are leaders in education and research, and therefore play a key role in the processes of cultural and social change [24]. Against this backdrop, universities may promote the sustainable development of society as a whole by reducing the negative impacts of their activities on the economy, society, and the environment [25] as well as fostering the inclusion of green issues in curricula [26] and research programs [27]. Additionally, higher education institutions play a strategic role as a driver of regional economic growth [28] and social and territorial cohesion [22]. Accordingly, universities may actively contribute to sustainability both internally (i.e., as an organization) and externally (i.e., as an agent in the region) [29].

Thus, sustainability has become a cornerstone for university management [24]. Accordingly, in recent years, higher education institutions have increasingly incorporated sustainability into the different dimensions of their activities. Such dimensions include [3]: (i) campus operations, which comprises green building, waste management, sustainable procurement, and sustainable mobility [25]; (ii) teaching, where "more efforts are needed to integrate sustainability into curricula" [30] (p. 1160); (iii) research, which represents the core activities of any university; and, finally, (iv) community engagement, as it is more and more important for universities to involve stakeholders (including not only students, faculty, and administrative staff, but also local firms, government, and society at large) 
in the institution's transition to sustainability [10,31]. When a university implements sustainability throughout all these dimensions, it may be considered "sustainable" or, with a similar meaning, "green" [29]. In other words, the sustainable strategy of a higher institution needs to take into consideration all these different perspectives jointly [32].

Additionally, such considerations shed light on the fact that nowadays universities are "complex systems" [4] that must move away from merely focusing on teaching and research and actively seek the engagement of stakeholders [33], including students, faculty, administrative staff, public administration, companies, and civil society [34]. Indeed, the active involvement of stakeholders is a critical element for effective implementation of sustainable principles. Trencher et al. [35] considered such "co-creation for sustainability" as a new academic task of universities that requires a complex network of communication among universities themselves and their stakeholders to truly allow an effective engagement.

Based on the above, it should be clear that communication and engagement are inherently interconnected [36]. In this regard, social media platforms (SM) are particularly well-suited for fostering dialogic communication, which refers to the process in which one party (i.e., an organization) interacts with another (i.e., the individual stakeholder) in a two-way dialogue through digital platforms in which both parties can exchange information, opinions, and experiences [37]. Indeed, regardless of the different types of SM (e.g., Facebook, Instagram, Twitter, and YouTube), the main feature of these platforms is that they recognize stakeholders as partners and creators of digital content, not just clients or users [38,39]. Precisely in this sense, Ramírez and Tejada [40] (p. 703) highlighted that SM are "engagement (data rich) vehicles of authentic content and stakeholder interaction." Accordingly, SM have deeply changed how organizations connect with their stakeholders by allowing them to receive real-time feedback about online announcements and involve stakeholders in a two-way conversation that can potentially produce engagement $[13,41,42]$. However, prior studies found that, despite the increasing use of SM, the level of engagement substantially remains too low [39].

Consequently, in recent years, Internet strategies have seen a substantial shift from a primary focus on information to a focus on cooperation and communication [43]. This change of communication model has affected all kinds of organizations, including universities [9]. Such institutions have been increasingly embracing the use of SM to interact more actively with and obtain feedback from students, professors, local communities, and others [11,12]. Some higher education institutions also use SM in their recruitment activities [20]; indeed, some studies have revealed that universities using SM interactively have higher levels of student recruitment demand than universities ignoring social activity [44].

While there are several studies investigating the implementation of sustainability within university activities e.g., [45-47], literature that has analyzed the use that higher education institutions make of SM is still scarce [48]. In this sense, according to So-Turan and Lambrechts [30], the literature in this field is concentrated around two topics: environmental sustainability, and the inclusion of green issues in teaching and curricula. Moreover, Ott et al, [49] called for more understanding of "what" and "how" universities are communicating about sustainability using online tools. Accordingly, we found few academic contributions that address the role of SM in disseminating the issue of sustainability in higher education and establishing a stakeholder dialogue. According to Hamid et al. [21], it is possible to identify two different motivations for the lack of studies about SM in the higher education sector. The first could be linked to the traditional one-way communication tools used in this kind of institutions. Indeed, universities traditionally adopt instruments for sustainability communication that are designed for limited interactions and for a single way communication such as websites, e-mails, newsletters, and magazines. However, as earlier discussed, stakeholder involvement is crucial to ensure that sustainability programs are truly realized, and the goals really achieved [50,51]. The second reason that could explain the lack of studies about this topic concerns the fact that the use of SM is still in an early stage, and universities have only recently started to adopt social platforms for sustainability communication. 
In this vein, this paper aims to fill the literature gap, acknowledging that SM may contribute to the effectiveness of a university's communication and dialogue with stakeholders also in the context of sustainability disclosure.

\section{Research Method and Data Collection}

This study has an exploratory nature and combines qualitative and quantitative approaches. In particular, we applied the single-case-study method, as it allows for a deep investigation of the practical aspects of a phenomenon in its real context and, therefore, it can answer the questions about "how" or "why" [52].

More precisely, we explored the case of the University of Florence (hereinafter, also simply referred to as "the University"). Several reasons support this choice. First, this institution is among the 10 largest Italian universities, having more than 52,000 students enrolled, about 3200 academic and non-academic staff, and approximately 280 educational programs. Second, it is one of the signers of some important declarations in the sustainability field, such as The Magna Charta Universitatum and Copernicus University Charter for Sustainable Development [53]. Third, it ranks fourth (alongside the University of Parma) among the Italian higher education institutions in the University Impact Ranking 2019 drawn up by the international weekly magazine Times Higher Education. Last but not least, the University has a Facebook page (Unifi: Sustainable University) as well as a website (www.ateneosostenibile.unifi.it) entirely dedicated to the topic of sustainability. This is particularly interesting since, as Hamid et al. [21] pointed out, universities may enhance their legitimacy about sustainability communication by creating a social Facebook account specifically devoted to disclosing information about green initiatives of the institution. Furthermore, the University of Florence, in their strategic plan for 2019-2021, stated that communication through social media is one of the main channels for fostering the University's research results, teaching information, and organizational data. Based on this, the University of Florence may be considered as a very interesting case to explore sustainability issues in a wide academic community.

This research refers to the year 2019 and comprises different steps. Within the first step, we examined the official Facebook (FB) profile of the University of Florence with the aim of collecting all posts related to sustainability issues. To this end, a manual search was carried out using the keywords "Sosten *" and "Sustain *"; for every single post published by the University about sustainability in 2019, we collected the number of likes, shares, and comments. We also collected the number of followers (i.e., the number of Facebook users selected to "like" the official profile of the University). Subsequently, we analyzed all of the posts published on the FB page "Unifi: Sustainable University" by the institution itself, also writing down the followers' number. In this case, given that the page is monothematic and concerns only the issue of sustainability, we did not need to identify the posts to be analyzed. Moreover, in order to realize the triangulation of the data, we analyzed other additional data resources, like the University websites, the social report, and the strategic plan.

In the second step, we carried out a content analysis on the posts to identify the most debated topics and the stakeholders' reactions. Content analysis, indeed, is the most frequently applied method in dialogic communication studies [54]. More in detail, we categorized the content of each post in one of the following categories: campus operations, teaching, research, and community engagement. These categories are widely recognized in the literature to be four crucial aspects of a "green university" [4,31]. Indeed, such an institution can be seen as a higher education institution that is managed in respect of green economic, social, and environmental practices, and that fulfils its function of teaching, research, and community engagement in ways to favor the transition of the society toward sustainability [3]. Although the literature also identifies other important dimensions of a green university (such as mission, vision, and sustainability reporting), a preliminary analysis of the posts' content led us to adopt the four abovementioned categories to analyze the content of each Facebook post. This choice is also consistent with the fact that, as pointed out by Velazquez et al. [3], all the sustainability initiatives of universities are organized into these four pillars, through which such institutions optimize their role as agents of change [55]. 
In order to carry out this phase of the study, specific guidelines were defined and used by the research team, which was composed of six members: three academic supervisors (one of which was the coordinator of the content analysis), a young researcher, and two master level students. Some pilot tests of the coding procedure were conducted to discuss unclear or ambiguous interpretations of coding rules. Subsequently, we divided the workload among two teams (for a total of four persons), each of which comprised two analysts that examined the same text-units. The coordinator of the content analysis supervised the entire process and compared the results obtained by two teams to ensure that there were no differences of interpretation of the content of the posts. All in all, we obtained a Cohen's $\kappa$ coefficient of inter-reliability of 0.8 , which can be considered very good [56].

During the third research step, we applied the three dimensions highlighted in the literature [57-60] (i.e., popularity, commitment, and virality) to evaluate the interaction level in sustainability issues. The number of "likes" represents the "popularity" of the SM audience and is measured by the number of "likes" for each FB post. The "commitment" shows stakeholders' interaction and is assessed through the number of their comments; in this sense, a higher number of comments means a higher commitment. Finally, the "virality" is the number of shares made by stakeholders and shows the stakeholders' commitment to disseminating the post. A higher number of likes, shares, and comments suggests a consequently higher engagement between the organization and its stakeholders [42].

Finally, we discussed the results obtained through the previous research steps with the board of the University of Florence, especially with the pro-rector for communication and public engagement and the pro-rector for sustainability. The interviews were then recorded on a digital device and transcribed.

\section{Results and Discussion}

The University of Florence is particularly active on social media, as it has official profiles on the several platforms (i.e., Facebook, Twitter, Instagram, YouTube, LinkedIn, Isuu, and Telegram). This study focuses on FB because it is the most used social media globally with 2.44 billion active users [61] and because the University has activated an additional FB profile dedicated to sustainability issues. In this regard, the pro-rector for communication and public engagement stated: "There is a very close link between the university communication area and sustainability issues. Actually, the issues, research, and actions concerning sustainability are systematically communicated both on the website and on the social profiles of the University. This is because, nowadays, public opinion shows a great sensitivity towards green challenges".

This study was carried out in March 2020 and, as stated in the previous section, analyzed both the University's official FB page and the monothematic "Unifi: Sustainable University" profile. These pages are followed by 54,225 and 1071 people, respectively. The different number of followers reflects the fact that people interested in the University's activities (in particular, students, and academic and non-academic staff) mainly visit the official Facebook profile; in fact, only some of them are particularly interested in sustainability issues and then motivated to search for additional information on the second profile. Moreover, "Unifi: Sustainable University" is more recent than the official page; the first was created in May 2016 and the second in October 2013.

The first step of the study focused on the search for sustainability-related posts. On the one hand, research conducted on the official University page using the keywords "Sosten *" and "Sustain *" gave a result of 85 posts published during the year 2019. Posts shared from other pages, mere changes of the cover image, and service messages (related to the University's closed days or holiday greetings) were excluded from the analysis. Our results show that, out of 578 posts published in the same period by the University, $14.7 \%$ were related to the sustainability issue. On the other hand, the amount of the posts published on the "Unifi: Sustainable University" page was 76. In this sense, previous studies stated that sustainability in the higher education sector was not widely diffused between students and staff through SM [21]. Our research reveals that a significant number of posts was dedicated to the sustainability issue in the University communication approach. Therefore, the institution appears to be prone to disseminating a sustainable lifestyle among the academic community. 
In order to depict a comprehensive overview of the Facebook activity by the University, we also analyzed the frequency of posting per week (Figures 1 and 2). The results show a low posting activity with the University publishing on average a total of about three posts per week (less than one post per day). In their study on the effect of posting frequency on users' engagement, Mariani et al. [62] found that high post frequency (more than five posts per day) negatively influences engagement level but at the same time posting one or two posts per day has a positive impact on engagement itself. Accordingly, the University should enhance the frequency at which published posts on sustainability in its official Facebook pages.

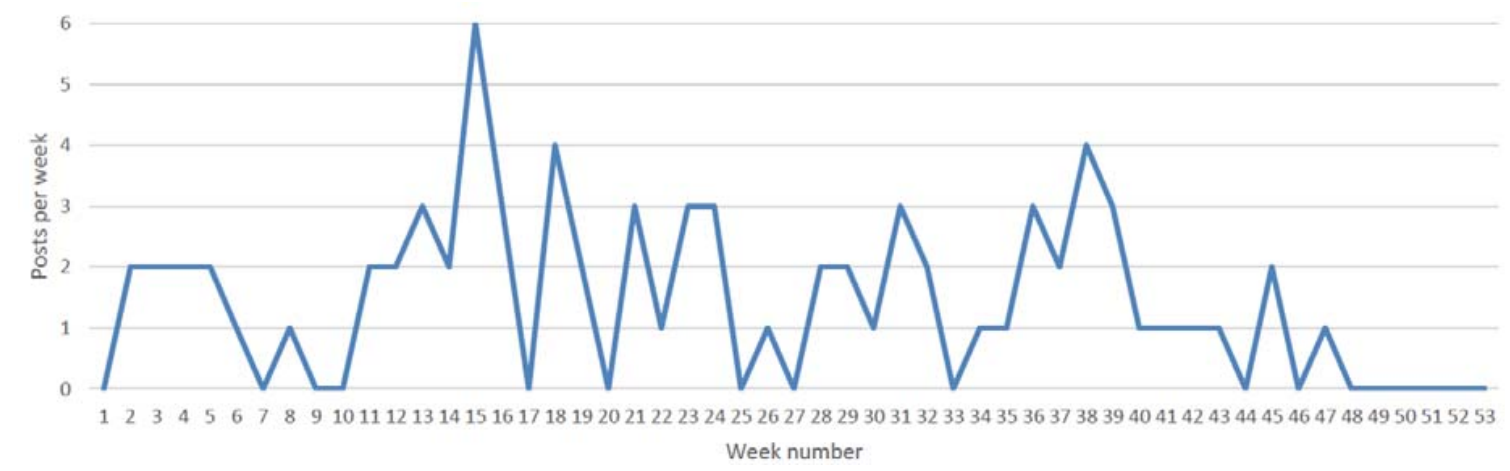

Figure 1. Frequency of posting per week for the monothematic "Unifi: Sustainable University" page.

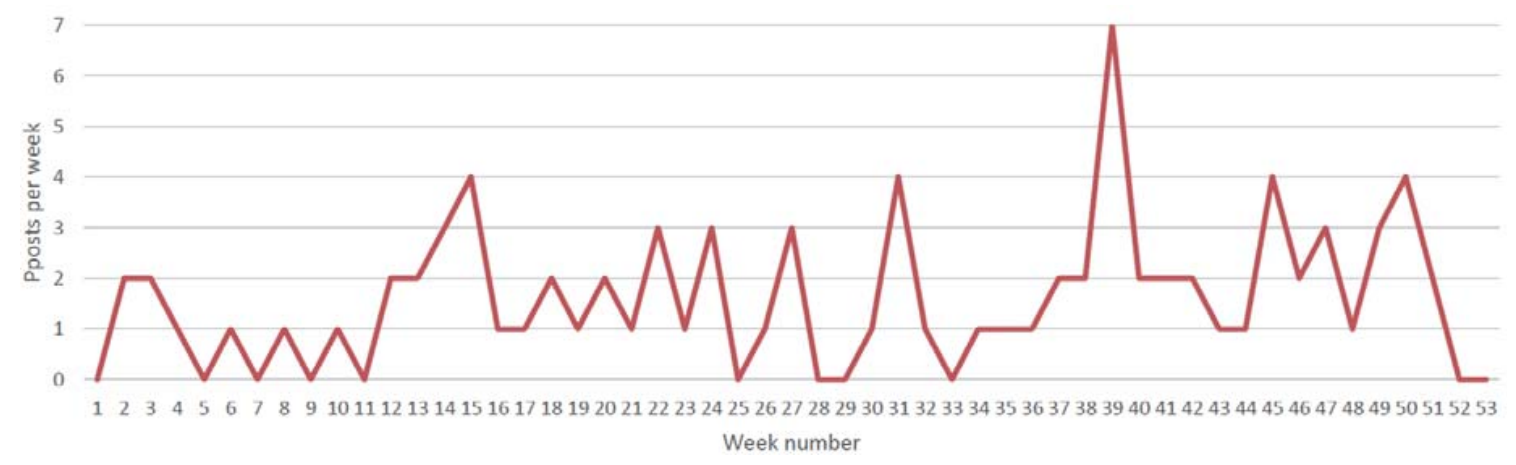

Figure 2. Frequency of posting per week for the University's official Facebook (FB) page.

The second phase of the research focused on the most debated sustainability-related topics. Consequently, we classified the post previously selected according to the four dimensions identified in the Section 3 (i.e., campus operations, teaching, research, and community engagement). In this regard, Table 1 offers sample transcripts of Facebook posts for each dimension.

We also noted that the 85 posts published by the University are in the majority of cases attributable to community engagement dimension, followed by research, teaching, and campus operations. The study obtained the same results with reference to the analysis of the 76 posts published on the "Unifi: Sustainable University" page (Table 2). These findings differ from previous studies that pointed out prevalent attention to the environmental aspect $[32,63]$. Indeed, our study reveals that most posts are related to the community engagement dimension and typical university activities (i.e., teaching and research). 
Table 1. Transcripts of sample Facebook posts published by the University of Florence.

\begin{tabular}{|c|}
\hline Campus Operations Dimension \\
\hline $\begin{array}{l}\text { Campus Operations Dimension } \\
\text { "\#WorldWaterDay | The University is committed every day to promote a more conscious use of water. } \\
\text { Among the actions that have been taken to date, there is the free delivery to students of about } 20,000 \\
\text { aluminium bottles and the installation of } 17 \text { water dispensers (called "Fontanelli") located in several } \\
\text { University's building." } \\
\text { [UniFI: Sustainable University, } 22 \text { March 2019] [27 likes, } 0 \text { shares, } 0 \text { comments] }\end{array}$ \\
\hline $\begin{array}{l}\text { Teaching Dimension } \\
\text { "The students of the "Advanced Materials Technology" course (master's degree in Chemistry) is visiting the } \\
\text { ALIA composting plant in Case Passerini [Florence]. Waste recycling is a good idea, but, in the case of the } \\
\text { organic one, it may cause bad smells!" [Photo of the visit] } \\
\text { [UniFI: Sustainable University, } 9 \text { April 2019] [10 likes, } 1 \text { share, } 0 \text { comments] }\end{array}$ \\
\hline $\begin{array}{l}\text { Research dimension } \\
\text { "The project of the University's research team guided by Dott. Riccardo Renzi for the construction of a } \\
\text { zero-energy building is among the winners of the International Sustainable Architecture Competition." } \\
\text { [UniFI, } 29 \text { May 2019] }\end{array}$ \\
\hline $\begin{array}{l}\text { Community Engagement Dimension } \\
\text { Are you aged between } 18 \text { and 35? Do you want to share your ideas to fight climate change? There will be } \\
\text { held in Florence, from Friday 25th to Sunday 27th October, the first Local Conference of Youth on Climate } \\
\text { Change (LCOY Italy), with the patronage of the University and the support of the DSU Toscana. Three days } \\
\text { of conferences and working tables aimed at elaborating practical proposals for local, national and } \\
\text { international institutions. Participation is free, but registration is required". } \\
\text { [UniFI, } 8 \text { October 2019] } \\
\text { [52 likes, } 26 \text { shares, } 2 \text { comments] }\end{array}$ \\
\hline
\end{tabular}

Table 2. Topics of University of Florence Facebook posts in 2019.

\begin{tabular}{ccccccccccc}
\hline & $\begin{array}{c}\text { Campus } \\
\text { Operations }\end{array}$ & Teaching & Research & \multicolumn{2}{c}{$\begin{array}{c}\text { Community } \\
\text { Engagement }\end{array}$} & Total \\
\hline $\begin{array}{c}\text { University of Florence } \\
\text { Unifi: Sustainable } \\
\text { University }\end{array}$ & 4 & $4.7 \%$ & 10 & $11.8 \%$ & 30 & $35.3 \%$ & 41 & $48.2 \%$ & 85 & $100 \%$ \\
& $4.0 \%$ & 7 & $9.2 \%$ & 22 & $28.9 \%$ & 44 & $57.9 \%$ & 76 & $100 \%$ \\
\hline
\end{tabular}

The fact that the majority of the posts are related to the community engagement category is not surprising. Indeed, social media platforms are, above all, a means of communicating information to organizations and people [13], and accordingly, they are used as engagement tools. On the other hand, research represents, coupled with teaching, the main activity of universities; therefore, it is natural that these dimensions represent the most communicated topics. However, the dissemination of research results through social media is by nature inefficient, as these tools-despite being sophisticated community relationship tools [64] — do not provide enough space for in-depth discussion. In this sense, any organization ends up communicating the most tangible results (for example, an application, a software, or a scientific publication) but not the progress in terms of increasing knowledge, which does not have an immediate external impact. In this regard, it is worth noting that the University often includes external links to scientific articles in FB posts concerning research issues that allows interested users to deal more with a specific topic.

The same considerations apply to teaching, for which different channels of communication are adopted even more frequently, for example the website, the open day, and student books. In contrast with the findings of Zutshi and Creed [53], sustainability is only one part of the educational path faced by the University's students, and indeed, the educational offerings do not currently include an academic program specifically dedicated to these issues. Other universities, in fact, seem to provide a variety of academic program with an emphasis on sustainability issues. In this regard, reflecting on the importance of the sustainability issue, the pro-rector for sustainability stated: "According to the interdisciplinary nature of sustainability, a specific training course for "sustainability managers" is still 
absent. However, the University's purpose is to organize a postgraduate course strictly devoted to green topics."

Finally, campus operations-which comprise green activities and initiatives taken in place by the University-represent the category least covered by posts. These posts mainly disclose specific waste reduction projects like the use of water dispensers and the reduction of plastic bottles replaced with aluminum ones. In this area, the projects essentially concern the academic and student communities that use different communication channels, from the website to screens inside the campus to word-of-mouth. The communication approach of the University of Florence is therefore oriented to disseminate specific recycling and waste reduction activities and seems to be less committed to broader natural ecology issues as other scholars found in different case studies [53].

In order to provide a comprehensive picture of the content of posts, we explored more in depth what the most used "words" were in the FB messages. The word cloud (Figure 3) reveals that the most used terms are the following: "Sustainable", "Sustainability", "Environment", "Researchers", "Development", "Students", "Engineering", "Bright", "Project" and "Program". These words appear to be related to the main categories of University activities (i.e., campus operations, teaching, research, and community engagement).

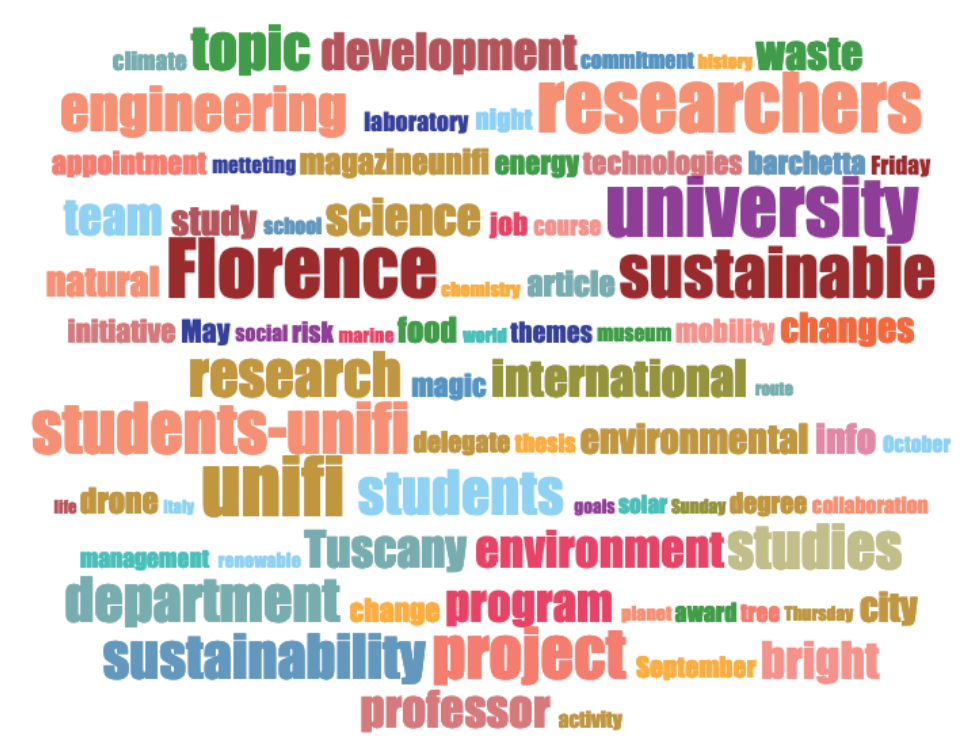

Figure 3. The word cloud.

The third phase examined the level of interaction between stakeholders and the University by analyzing the number of likes, shares, and comments with reference to the four sustainability issues previously identified and to both FB pages (Table 3). This type of analysis has so far never performed in previous studies on the website communication [49] and the use of SM for e-learning processes $[65,66]$.

Table 3. Number of likes, shares, and comments for each page and content category.

\begin{tabular}{ccccccc}
\hline \multirow{2}{*}{ Content of Post } & \multicolumn{3}{c}{ University of Florence } & \multicolumn{2}{c}{ Unifi: Sustainable University } \\
\cline { 2 - 7 } & Likes & Shares & Comments & Likes & Shares & Comments \\
\hline Campus operations & 342 & 77 & 22 & 85 & 9 & 6 \\
Research & 883 & 237 & 15 & 285 & 68 & 8 \\
Teaching & 249 & 42 & 1 & 33 & 5 & 1 \\
Community engagement & 1246 & 312 & 23 & 364 & 152 & 5 \\
Total & 2720 & 668 & 61 & 767 & 234 & 20 \\
\hline
\end{tabular}

These data highlight that stakeholders mostly interact on issues related to community engagement, followed by research, campus operations, and teaching. This probably also depends on the number 
of posts published for each of these topics, both on the official page and on the "Unifi: Sustainable University" page. Moreover, the interaction of the stakeholders takes place more frequently through "likes" and "shares" tools and more rarely with comments. This finding is consistent with previous research carried out in different sectors, such as museums [59], the public sector [57,67], and the hospitality industry [60].

Shifting the focus to the average values, the results highlight some interesting differences compared to what has just been noted (Table 4).

Table 4. Average number of likes, shares, and comments for each page and content category.

\begin{tabular}{ccccccc}
\hline \multirow{2}{*}{ Content of Post } & \multicolumn{3}{c}{ University of Florence } & \multicolumn{2}{c}{ Unifi: Sustainable University } \\
\cline { 2 - 7 } & Likes & Shares & Comments & Likes & Shares & Comments \\
\hline Campus operations & 85.5 & 19.3 & 5.5 & 28.3 & 3.0 & 2.0 \\
Research & 29.4 & 7.0 & 0.5 & 13.0 & 3.1 & 0.4 \\
Teaching & 24.9 & 4.2 & 0.1 & 4.8 & 0.2 & 0.0 \\
Community engagement & 30.4 & 7.6 & 0.1 & 8.3 & 3.5 & 0.1 \\
Total & 170.2 & 38.1 & 6.2 & 54.4 & 9.7 & 2.5 \\
\hline
\end{tabular}

Indeed, the average values show, for both FB profiles, a deeper interaction for the posts in the campus operations category. This may be due to the fact that the majority of the followers of both pages comprises students and academic and non-academic staff. Indeed, although the list of the university stakeholders is a long one $[9,68]$, such people are those who really "live" the university; indeed, they are those who experience the campuses and facilities, and take advantage of any new features introduced, such as water dispensers, recycling points, and pit stop points for young student mothers. Furthermore, even if it is strongly contained in absolute value, for this category of posts there is also an average number of comments ( 5.5 for the University's Facebook page and 2.0 for "Unifi: Sustainable University") that is higher compared to the other categories, which have on average less than one comment for each published post.

Overall, the posts for the community engagement, research, and teaching categories on the University's FB page show similar average values for likes, shares, and comments, even if with slightly more contained results for the last category. Instead, for the "Unifi: Sustainable University" page, the most liked category, after campus operations, is the research one, followed by community engagement and teaching. This result could be consistent with a specific objective pursued by the University. Indeed, the pro-rector for communication and public engagement claimed that "Social media is one of the channels by which we disseminate the results of research about sustainability challenges, especially using the forms of storytelling that more attract the interest of the stakeholders".

Our results show that the level of stakeholder interaction is, in general, rather low and limited to likes and shares, more rarely producing comments. About this, the pro-rector for communication and public engagement stated that "The engagement of the University's stakeholders on social media about sustainability issues and about other topics in general represents a great challenge. The goal is certainly achievable, but only step by step".

To reach a "two-way communication" about the sustainability issue, it would be essential that the University actively respond to stakeholders' requests. Actually, there is low University reactivity to the followers' requests, as the organization's responses are rare. Therefore, also for sustainability issues, the results confirm the low level of interaction by organizations that are used to not responding to the comments and provocations of FB users [9]. Moreover, the results point out that the University should guide and support the conversation on sustainability in order to stimulate discussion between stakeholders and to spread greater sensitivity with respect to this issue. In this regard, Ballestar et al. [69] noted that the lack of a person to lead the conversation is a widespread problem in almost all social profiles of organizations that deal with sustainability. To be conclude, the pro-rector for sustainability stated that "The university has a mission: first of all, it is necessary to improve green activities, to carry 
out studies that have to be truly sustainable and that allow the development of knowledge to spread to the students. Communication and interaction with stakeholders are the elements that enable us to complete the path. However, communicating sustainability is not an easy challenge, as it has many senses and, as it is often said, it is an interdisciplinary issue".

\section{Conclusions}

In recent years, universities have paid increasing attention to sustainability, attempting to integrate these issues into the different dimensions of their activity (i.e., campus operations, teaching, research, and community engagement). At the same time, scholars have observed a growing trend in using social media within universities' activities for different purposes, like establishing a dialogue with students as well as academic and non-academic staff and other stakeholders.

However, the literature review found several contributions that focused separately on sustainability and on the use of social media in universities, but so far a lack of studies that merge these two aspects. In other words, scholars have not considered the link between the emerging issue of sustainability in universities and the opportunity to disseminate this topic using social media. Indeed, SM are particularly well-suited for fostering dialogic communication, which refers to the process in which one party (i.e., an organization) interacts with another (i.e., the individual stakeholder) in a two-way dialogue through digital platforms.

In this perspective, the aim of this study was to investigate more in depth the interaction between sustainability practices in universities and the users of social media.

In the first step of the research, we examined the FB profiles of the University of Florence with the aim of collecting all sustainability-related posts. The results, based on a content analysis, demonstrate increasing attention to sustainability issues, with 161 posts published during 2019, and accordingly show a close link between university communication and sustainability topics. Previous studies have found that sustainability in higher education was not widely diffused between students and staff through SM [21]. Our research seems to define a different approach for the University of Florence and a new use of SM for sustainability dissemination. In this sense, SM represents a powerful tool for universities in order to disseminate sustainability practices within the academic community and the stakeholders.

Moreover, in the second step, we analyzed the topics addressed by the posts on sustainability, and the results show a majority of cases attributable to the community engagement category, followed by research, teaching, and campus operations. While previous research pointed out prevalent attention to the environmental aspect [32], our results suggest that most posts are related to the community engagement dimension. However, this result is not surprising because SM are mainly a means of engagement by communicating information to organizations and people in a fast and effective way [66]. In other words, SM has the first goal of facilitating communication between people and organizations using digital devices, and for this reason, these tools are well-suited for favoring users' engagement from academic and non-academic staff to students and citizens.

The third phase of the research examined the level of interaction between stakeholders and the University of Florence by analyzing the number of likes, shares, and comments concerning the four categories. The results show a rather low of interaction of followers through SM. In particular, the interaction is realized with likes and shares, while comments are rare. Moreover, the results show that, when stakeholders decide to interact, this activity is realized mainly in posts related to the community engagement dimension, followed by research, campus operations, and teaching. In this sense, the experience of the University confirms previous studies carried out in different sectors such as museums, the hospitality industry, and the public sector where scholars discover that SM are currently used in a traditional "one-way communication" without considering the power of these tools.

Finally, this study highlights that stakeholder engagement on SM about sustainability issues represents a great challenge for the University. The goal seems to be achievable, but only in the medium term. Moreover, to reach real "two-way communication", it is fundamental that the University also 
respond actively and promptly to stakeholder requests. In this sense, the research reveals low reactivity to followers' requests, as the organization's responses are rare. To reach this goal, the University needs to guide and support the conversation on SM, stimulating a discussion between stakeholders on sustainability topics.

Although in recent years communication about sustainability has been increasing, the main concern remains to modify the behavior of people towards sustainable practices. In this context, SM could play a relevant role in order to reach a wide number of people and increase their awareness of sustainability issues. In this sense, this paper calls for new studies where scholars investigate more in depth the contribution of SM in developing a model of sustainable universities. From a managerial point of view, the case of the University of Florence shows the importance to create a SM channel specifically devoted to the sustainability dissemination for engaging the academic community and the other stakeholders. However, the institution needs to be more involved in the use of SM channels, especially replying in a timely manner to followers' comments and stimulating the digital debate.

This research suffers from numerous limitations. First, the University of Florence is a single case study. Accordingly, the results should be compared with other case studies in order to verify the possibility of generalizing our results. Also, future research might couple results coming from SM analysis with interviews with other University's officials for sustainability operations, especially the Green Office's Chair. Second, the analysis is based on Facebook posts published in a single year (2019). Future studies could investigate different SM (like Twitter, Instagram, Pinterest, and YouTube) and take into consideration a longer period of time. Third, future research could investigate the topic with reference to other types of state and non-state universities or considering other countries, also using quantitative methods. The University of Florence is a general state university, and, in the future, it could be interesting to analyze different institutions based more on teaching or research.

Author Contributions: This work represents a joint study by the authors. Section 1, E.G.; Sections 3 and 5, A.R.; Section 4, S.F.; Section 2, M.C. All authors have read and agreed to the published version of the manuscript.

Funding: This research received no external funding.

Conflicts of Interest: The authors declare no conflict of interest.

\section{References}

1. Pilař, L.; Stanislavská, L.K.; Pitrova, J.; Krejčí, I.; Tichá, I.; Chalupová, M. Twitter Analysis of Global Communication in the Field of Sustainability. Sustainability 2019, 11, 6958. [CrossRef]

2. Cooper, L.; Gorman, D. A holistic approach to embedding social responsibility in a university-Fostering collaboration between researchers, students and operations. In Handbook of Sustainability Science and Research; Leal Filho, W., Ed.; Springer: Cham, Switzerland, 2018; pp. 177-192.

3. Tilbury, D. Higher education for sustainability. A global review of commitment and progress. In Higher Education in the World 4. Higher Education's Commitment to Sustainability: From Understanding to Action (GUNI Series on the Social Commitment of Universities); Palgrave Macmillan: Basingstoke, UK, 2012; pp. 18-22.

4. Velazquez, L.; Vega, N.E.M.; Platt, A.; Taddei, J. Sustainable university: What can be the matter? J. Clean. Prod. 2006, 14, 810-819. [CrossRef]

5. Yuan, X.; Zuo, J.; Huisingh, D. Green Universities in China-What matters? J. Clean. Prod. 2013, 61, 36-45. [CrossRef]

6. Lozano, R.; Lukman, R.; Lozano, F.J.; Huisingh, D.; Lambrechts, W. Declarations for sustainability in higher education: Becoming better leaders, through addressing the university system. J. Clean. Prod. 2013, 48, 10-19. [CrossRef]

7. Lambrechts, W.; Van Liedekerke, L.; Van Petegem, P. Higher education for sustainable development in Flanders: Balancing between normative and transformative approaches. Environ. Educ. Res. 2017, 24, 1284-1300. [CrossRef]

8. Ávila, L.V.; Filho, W.L.; Brandli, L.; MacGregor, C.J.; Molthan-Hill, P.; Özuyar, P.G.; Moreira, R.M. Barriers to innovation and sustainability at universities around the world. J. Clean. Prod. 2017, 164, 1268-1278. [CrossRef] 
9. Bellucci, M.; Biagi, S.; Manetti, G. Dialogic Accounting and Stakeholder Engagement Through Social Media: The Case of Top-Ranked Universities. Rev. High. Educ. 2019, 42, 1145-1184. [CrossRef]

10. Blanco-Portela, N.; Benayas, J.; Pertierra, L.R.; Lozano, R. Towards the integration of sustainability in Higher Education Institutions: A review of drivers of and barriers to organisational change and their comparison against those found of companies. J. Clean. Prod. 2017, 166, 563-578. [CrossRef]

11. Aquilani, B.; Lovari, A. Social networks and university communication: Is Facebook a new opportunity? An Italian exploratory study. In Proceedings of the 12th International QMOD and Toulon-Verona Conference on Quality Service Sciences (ICQSS), Verona, Italy, 27-29 August 2009.

12. Bateman, D.; Wilems, J. Facing off: Facebook and higher education. In Misbehavior Online Higher Education: Cutting-Edge Technologies in Higher Education; Wankel, L.A., Wankel, C., Eds.; Emerald: Bingley, UK, 2012; pp. 53-79.

13. Kaplan, A.M.; Haenlein, M. Users of the world, unite! The challenges and opportunities of Social Media. Bus. Horiz. 2010, 53, 59-68. [CrossRef]

14. Deborah, A.; Arnaboldi, M. A Measurement Framework for Assessing the Contribution of Social Media to Public Engagement: An empirical analysis on Facebook. Public Manag. Rev. 2015, 18, 1-19. [CrossRef]

15. Waters, R.D.; Jamal, J.Y. Tweet, tweet, tweet: A content analysis of nonprofit organizations' Twitter updates. Public Relat. Rev. 2011, 37, 321-324. [CrossRef]

16. Xifra, J.; Grau, F. Nanoblogging PR: The discourse on public relations in Twitter. Public Relat. Rev. 2010, 36, 171-174. [CrossRef]

17. Manetti, G. The quality of stakeholder engagement in sustainability reporting: Empirical evidence and critical points. Corp. Soc. Responsib. Environ. Manag. 2011, 18, 110-122. [CrossRef]

18. Waters, R.D.; Canfield, R.R.; Foster, J.M.; Hardy, E.E. Applying the dialogic theory to social networking sites: Examining how university health centers convey health messages on Facebook. J. Soc. Mark. 2011, 1, 211-227. [CrossRef]

19. Lovari, A.; Mazzei, A.; Vibber, K. University-student relations: Dynamic framework in offline and digital environments. In Public Relations as Relations as Relationship Management: A Relational Approach to the Study and Practice of Public Relations; Ki, E.J., Kim, J.N., Ledingham, J., Eds.; Routledge: New York, NY, USA, 2015.

20. Barnes, N.G.; Mattson, E. Social media and college admission: The first longitudinal study. In Center for Marketing Research; University of Massachussets: Darmouth, MA, USA, 2009.

21. Hamid, S.; Ijab, M.T.; Sulaiman, H.; Anwar, R.M.; Norman, A.A. Social media for environmental sustainability awareness in higher education. Int. J. Sustain. High. Educ. 2017, 18, 474-491. [CrossRef]

22. Salvioni, D.M.; Franzoni, S.; Cassano, R. Sustainability in the Higher Education System: An Opportunity to Improve Quality and Image. Sustainability 2017, 9, 914. [CrossRef]

23. Koehn, P.H.; Uitto, J.I. Universities and the sustainable development future. In Evaluating Higher-Education Contributions to the 2030 Agenda; Routledge: London, UK, 2017.

24. Blasco, N.; Alijarde, M.I.B.; Labrador, M. Assessing Sustainability and Its Performance Implications: An Empirical Analysis in Spanish Public Universities. Sustainability 2019, 11, 5302. [CrossRef]

25. Filho, W.L.; Will, M.; Salva, A.L.; Adomßent, M.; Grahl, A.; Spira, F. The role of green and Sustainability Offices in fostering sustainability efforts at higher education institutions. J. Clean. Prod. 2019, 232, 1394-1401. [CrossRef]

26. Pauw, J.B.-D.; Gericke, N.; Olsson, D.; Berglund, T. The Effectiveness of Education for Sustainable Development. Sustainability 2015, 7, 15693-15717. [CrossRef]

27. Waas, T.; Verbruggen, A.; Wright, T.S. University research for sustainable development: Definition and characteristics explored. J. Clean. Prod. 2010, 18, 629-636. [CrossRef]

28. Fuster, E.; Padilla-Meléndez, A.; Lockett, N.; Del-Aguila-Obra, A.-R. The emerging role of university spin-off companies in developing regional entrepreneurial university ecosystems: The case of Andalusia. Technol. Forecast. Soc. Chang. 2019, 141, 219-231. [CrossRef]

29. Dagiliūtè, R.; Liobikienè, G.; Minelgaitè, A. Sustainability at universities: Students' perceptions from Green and Non-Green universities. J. Clean. Prod. 2018, 181, 473-482. [CrossRef]

30. So-Turan, S.; Lambrechts, W. Sustainability disclosure in higher education. A comparative analysis of reports and websites of public and private universities in Turkey. Int. J. Sustain. High. Educ. 2019, 20, 1143-1170. [CrossRef] 
31. Wright, T. Definitions and frameworks for environmental sustainability in higher education. High. Educ. Policy 2002, 15, 105-120. [CrossRef]

32. Too, L.; Bajracharya, B. Sustainable campus: Engaging the community in sustainability. Int. J. Sustain. High. Educ. 2015, 16, 57-71. [CrossRef]

33. Dentoni, D.; Bitzer, V. The role(s) of universities in dealing with global wicked problems through multi-stakeholder initiatives. J. Clean. Prod. 2015, 106, 68-78. [CrossRef]

34. Sassen, R.; Azizi, L. Voluntary disclosure of sustainability reports by Canadian universities. J. Bus. Econ. 2017, 88, 97-137. [CrossRef]

35. Trencher, G.; Yarime, M.; McCormick, K.; Doll, C.N.; Kraines, S. Beyond the third mission: Exploring the emerging university function of co-creation for sustainability. Sci. Public Policy 2013, 41, 151-179. [CrossRef]

36. Taylor, M.; Kent, M.L. Dialogic Engagement: Clarifying Foundational Concepts. J. Public Relat. Res. 2014, 26, 384-398. [CrossRef]

37. Kent, M.L.; Taylor, M. Building dialogic relationships through the world wide web. Public Relat. Rev. 1998, 24, 321-334. [CrossRef]

38. Chua, A.Y.K.; Goh, D.H.; Ang, R.P. Web 2.0 applications in government websites: Prevalence, use, and correlations with perceived website quality. Online Inf. Rev. 2012, 36, 175-195. [CrossRef]

39. Manetti, G.; Bellucci, M. The use of social media for engaging stakeholders in sustainability reporting. Account. Audit. Account. J. 2016, 29, 985-1011. [CrossRef]

40. Ramírez, Y.; Tejada, Á. Digital transparency and public accountability in Spanish universities in online media. J. Intellect. Cap. 2019, 20, 701-732. [CrossRef]

41. Carrasco, P.G.; Guillamon-Saorin, E.; Osma, B.G. Stakeholders versus Firm Communication in Social Media: The Case of Twitter and Corporate Social Responsibility Information. Eur. Account. Rev. 2020, 1-32. [CrossRef]

42. Manetti, G.; Bellucci, M.; Bagnoli, L. Stakeholder Engagement and Public Information Through Social Media: A Study of Canadian and American Public Transportation Agencies. Am. Rev. Public Adm. 2016, 47,991-1009. [CrossRef]

43. Fuchs, C. Internet and Society: Social Theory in the Information Age; Routledge: New York, NY, USA, 2008.

44. Rutter, R.; Roper, S.; Lettice, F. Social media interaction, the university brand and recruitment performance. J. Bus. Res. 2016, 69, 3096-3104. [CrossRef]

45. Sonetti, G.; Lombardi, P.; Chelleri, L. True Green and Sustainable University Campuses? Toward a Clusters Approach. Sustainability 2016, 8, 83. [CrossRef]

46. Wang, J.; Yang, M.; Maresova, P. Sustainable Development at Higher Education in China: A Comparative Study of Students' Perception in Public and Private Universities. Sustainability 2020, 12, 2158. [CrossRef]

47. Xiong, W.; Mok, K.-H. Sustainability Practices of Higher Education Institutions in Hong Kong: A Case Study of a Sustainable Campus Consortium. Sustainability 2020, 12, 452. [CrossRef]

48. Knight, C.; Kaye, L.K. 'To tweet or not to tweet?' A comparison of academics' and students' usage of Twitter in academic contexts. Innov. Educ. Teach. Int. 2014, 53, 1-11. [CrossRef]

49. Ott, H.; Wang, R.; Bortree, D. Communicating Sustainability Online: An Examination of Corporate, Nonprofit, and University Websites. Mass Commun. Soc. 2016, 19, 671-687. [CrossRef]

50. Sobreiro, V.A.; Jabbour, C.J.C. Toward a Greener University: Some lessons from the Brazilian experience. Environ. Qual. Manag. 2007, 16,69-73. [CrossRef]

51. Alshuwaikhat, H.; Abubakar, I.R. An integrated approach to achieving campus sustainability: Assessment of the current campus environmental management practices. J. Clean. Prod. 2008, 16, 1777-1785. [CrossRef]

52. Yin, R.K. Case Study Research and Applications: Design and Methods; Sage: Los Angeles, CA, USA, 2018.

53. Zutshi, A.; Creed, A. Declaring Talloires: Profile of sustainability communications in Australian signatory universities. J. Clean. Prod. 2018, 187, 687-698. [CrossRef]

54. Wirtz, J.G.; Zimbres, T.M. A systematic analysis of research applying 'principles of dialogic communication' to organizational websites, blogs, and social media: Implications for theory and practice. J. Public Relat. Res. 2018, 30, 5-34. [CrossRef]

55. McMillin, J.; Dyball, R. Developing a whole-of-university approach to educating for sustainability linking curriculum, research and sustainable campus operations. J. Educ. Sustain. 2009, 3, 55-64. [CrossRef]

56. Bryman, A. Social Research Methods; Oxford University Press: Oxford, UK, 2016. 
57. Bellucci, M.; Manetti, G. Facebook as a tool for supporting dialogic accounting? Evidence from large philanthropic foundations in the United States. Account. Audit. Account. J. 2017, 30, 874-905. [CrossRef]

58. Camarero, C.; Garrido, M.-J.; San-Jose, R. What Works in Facebook Content Versus Relational Communication: A Study of their Effectiveness in the Context of Museums. Int. J. Hum. Comput. Interact. 2018, 34, 1-16. [CrossRef]

59. Romolini, A.; Fissi, S.; Gori, E. Visitors engagement and social media in museums: Evidence from Italy. Int. J. Digit. Cult. Electron. Tour. 2020, 3, 36-53. [CrossRef]

60. Su, N.; Reynolds, D.; Sun, B. How to make your Facebook posts attractive-A case of leading budget hotel brand fan page. Int. J. Contem. Hospit. Manag. 2015, 27, 1772-1790. [CrossRef]

61. Statista. Most Popular Social Networks Worldwide as of January 2020, Ranked by Number of Active Users. Available online: https://www.statista.com/statistics/272014/global-social-networks-ranked-by-number-ofusers/ (accessed on 5 April 2020).

62. Mariani, M.M.; Felice, M.; Mura, M. Facebook as a destination marketing tool: Evidence from Italian regional Destination Management Organizations. Tour. Manag. 2016, 54, 321-343. [CrossRef]

63. Engrenfeld, J.R. The roots of sustainability. MIT Sloan Manag. Rev. 2005, 46, 23-25.

64. Ang, L. Community relationship management and social media. J. Database Mark. Cust. Strat. Manag. 2011, 18, 31-38. [CrossRef]

65. Gulbahar, Y. Social networks from higher education students' perspectives. Anadolu J. Educ. Sci. Int. 2013, 3, $22-32$.

66. Irwin, C.; Ball, L.; Desbrow, B.; Leveritt, M. Students' perceptions of using Facebook as an interactive learning resource at university. Australas. J. Educ. Technol. 2012, 28, 1221-1231. [CrossRef]

67. Waters, R.D.; Burnett, E.; Lamm, A.; Lucas, J. Engaging stakeholders through social networking: How nonprofit organizations are using Facebook. Public Relat. Rev. 2009, 35, 102-106. [CrossRef]

68. Benneworth, P.; Jongbloed, B. Who matters to universities? A stakeholder perspective on humanities, arts and social sciences valorisation. High. Educ. 2009, 59, 567-588. [CrossRef]

69. Ballestar, M.; Cuerdo-Mir, M.; Freire-Rubio, M. The Concept of Sustainability on Social Media: A Social Listening Approach. Sustainability 2020, 12, 2122. [CrossRef]

(C) 2020 by the authors. Licensee MDPI, Basel, Switzerland. This article is an open access article distributed under the terms and conditions of the Creative Commons Attribution (CC BY) license (http://creativecommons.org/licenses/by/4.0/). 